\title{
Seed storage behaviour of Buxus wallichiana Baillon: An important woodcraft species of Indian Himalayan region
}

\author{
Manisha Thapliyal* \\ Forest Tree Seed Laboratory, Silviculture \& Forest Management Division, Forest \\ Research Institute, Dehradun -248 006 (Uttarakhand), India \\ Pravin Rawat \\ Forest Tree Seed Laboratory, Silviculture \& Forest Management Division, Forest \\ Research Institute, Dehradun -248 006 (Uttarakhand), India
}

*Corresponding author. E-mail: manishathapliyal98@gmail.com

\begin{abstract}
Seeds of Buxus wallichiana Baillon are dormant and not much information is available on their shelf life under storage conditions. Therefore, this study was conducted to investigate the seed storage behaviour of $B$. wallichiana, an important woodcraft species of the Indian Himalayan Region. Healthy matured fruits of $B$. wallichiana were collected from Matkangra block, Chakrata Forest Division of Uttarakhand. The seeds were extracted, cleaned, processed manually and their initial viability was tested through germination test. After initial viability determination, seeds were processed and placed in air-tight plastic boxes for storage at four temperatures viz., ambient room temperature (Control), $5^{\circ} \mathrm{C}, 15^{\circ}$ $\mathrm{C}$ and $-20^{\circ} \mathrm{C}$. Thereafter, at every two months interval, germination test was conducted to assess the viability of the stored seeds. The results revealed that the initial viability of freshly collected seeds was 26.66 per cent and it took 7.83 days to complete germination. After two months of storage the germination percentage increased in the seeds stored at all the temperatures going up to maximum $(73.33 \%)$ in the ones stored at $-20^{\circ} \mathrm{C}$ followed by $15^{\circ} \mathrm{C}(66.67 \%)$ as compared to $50 \%$ in the seeds stored at room temperature. Similarly, the mean germination time also increased proportionally, longest being 44 days for seeds stored at $-20^{\circ} \mathrm{C}$. Seeds stored at ambient room temperature lost viability completely at 6 months storage duration while almost half the viability was lost in seeds stored at $15^{\circ} \mathrm{C}(36.67 \%)$ and $-20^{\circ} \mathrm{C}(26.67 \%)$. From present study, it can be concluded that the longevity of the $B$. wallichiana seeds is around 12 months when the seeds are stored at lower temperatures, maintaining the viability about $23 \%$ at $5^{\circ} \mathrm{C}$ and $15^{\circ} \mathrm{C}$ and $16.67 \%$ at $-20^{\circ} \mathrm{C}$
\end{abstract}

Keyword: Buxus, Germination, Seed storage, Temperature, Viability

\section{Article Info}

DOI:10.31018/jans.v11i2.2045 Received: March 20, 2019

Revised: April 22, 2019

Accepted: April 28, 2019

\section{How to Cite}

Thapliyal, M. and Rawat, P. (2019). Seed storage behaviour of Buxus wallichiana Baillon: An important woodcraft species of Indian Himalayan region. Journal of Applied and Natural Science, 11(2): 311- 314 https://doi.org/10. 31018 /jans.v11i2.2045

\section{INTRODUCTION}

The Himalayan boxwood (Buxus wallichiana Baillon) is a dense leafy evergreen shrub or small tree found commonly in the western and central Himalayas at elevations ranging from $1200 \mathrm{~m}$ to 2900 $\mathrm{m}$ amsl, where it grows gregariously in patches in moist shady ravines. The wood is used to manufacture the precision instruments, boxes, turnery works, etc., while extracts of the leathery leaves and bark is used in local medicine (Govt. of India, 1986). But the species is facing severe threats in many parts of the Himalayan region because of its over exploitation for woodcrafts industry (Pant, 2011). Since, $B$. wallichiana has been identified as a potential species for reforestation in the denuded hill tops in higher elevations of upper and middle Himalayas, understanding the natural dispersal mechanisms, seed ecology and seed storage and survival processes can help to develop strate- gies for natural and artificial regeneration programmes (Viswanath et al. 2006). However, there is limited information on the germination requirements and seed storage behaviour of boxwood seeds. Thapliyal (1992) and Viswanath, (1999) have reported that the seeds of $B$. wallichiana are difficult to germinate in laboratory as well as in the nursery. Shirzad et al. (2013) reported reduction in the number of stands of $B$. hyrcana in Caspian forests due to its exploitation for wood. The seedling growth of other species like $B$. microphylla is reported to be irregular owing to erratic germination pattern. So, the seed storage study is very essential for determining shelf life and viability of various types of seeds for conservation and regeneration of species of high conservation concern. Good quality seed must be collected and should be stored properly according to the seed storage procedures to prevent loss of quality of 
seeds. Thus, the present study was undertaken to investigate the longevity of seeds of $B$. wallichiana at various storage temperatures and to develop a strategy for conserving the species ex-situ.

\section{MATERIALS AND METHODS}

Site and seed collection: Present study was conducted at the Forest Tree Seed Laboratory of Forest Research Institute, Dehradun. The seeds of $B$. wallichiana were collected in the month of September from Matkangra block near Jadi village of Chakrata Forest Division, Uttarakhand, India having Geo-coordinates $30^{\circ} 44.069^{\prime} \mathrm{N}$ and $77^{\circ} 50.621^{\prime} \mathrm{E}$ and altitude $2162 \mathrm{~m}$ amsl.

Initial parameters of the seed: After collection the initial parameters of fruits (colour, length, width, 100 fruit weight) and seeds (colour, length, width, 100 seed weight, purity, moisture content, and germination percentage) were studied. Fruit and seed colour was observed visually. Fruit and seed length was measured using digital calliper. The observations on weight of 100 fruits and seeds was taken in three replicates (ISTA, 2010). The purity percentage of the seeds was calculated after seed extraction using the formula:

Purity $\%=$ Weight of pure seed sample/Weight of total working sample $\times 100 \quad$...Eq.1 The moisture content (on fresh weight basis) of collected seeds was determined in three replications of 10 seeds each in oven at $103 \pm 1^{\circ} \mathrm{C}$ (ISTA, 2010) for $17 \pm 1$ hours using the following formula: Moisture content \%= Fresh weight- Oven dry weight/ Fresh weight $\times 100$

...Eq. 2

The germination trial was conducted in laboratory by placing four replications of 10 seeds each on moist Whatman filter paper in a petri dish $(14 \mathrm{~cm}$ diameter) and kept in a germinator at $25 \pm 1^{\circ} \mathrm{C}$. The seeds were considered as germinated when the radicle emerged about $0.5 \mathrm{~cm}$, thereby, germination per cent was calculated.

Germination \%= Number of germinated seeds/

Total seed sown $\times 100$

....Eq. 3

Germination value: Germination value is an index combining speed and completeness of seed germination.

Germination value (GV) was calculated by the method given by Czabator (1962).

Germination value $(G V)=$ Final $D S G * P V D S G$ ... Eq. 4

Where DSG = Daily Germination Speed $P V=$ Peak Value of DSG

Peak value is the highest value of Mean Daily Germination (MDG)/DSG.

DSG/MDG is calculated by dividing the cumulative germination percentage by the number of days since sowing.

Mean germination time (MGT): It is the time taken to complete germination under various treatments and was determined as Mean Germination Time (MGT) in days as under:
MGT $=\sum$ (daily germination $\times$ days $) /$ Number of seeds sown ....Eq.6

Seed storage experiment: The well cleaned, processed and initial viability determined seeds were desiccated to about $11 \%$ moisture content and then kept for storage at four temperatures viz. Ambient room temperature (Control), $5^{\circ} \mathrm{C}, 15^{\circ} \mathrm{C}$ and $-20^{\circ} \mathrm{C}$. Seeds were stored in plastic boxes at each temperature, in the month of November. The viability test of stored seeds was done at two months interval through germination test.

Statistical analysis: There were four treatments of storage temperatures $\mathrm{TO}=$ ambient room temperature (Control), $\mathrm{T} 1=5^{\circ} \mathrm{C}, \mathrm{T} 2=15^{\circ} \mathrm{C}$ and $\mathrm{T} 3=$ $20^{\circ} \mathrm{C}$ ) replicated four times. The data pertaining to the present study was analyzed using Complete Randomized Design and was analyzed by using software MS Excel (2007) and SPSS version 21.

\section{RESULTS}

The fruits of $B$. wallichiana were collected when they turned brownish in colour. The length and width of fruits was $8.98 \pm 0.5 \mathrm{~mm}$ and $8.39 \pm 0.47 \mathrm{~mm}$, while the weight of fruits (100 individuals) was $39.33 \pm 0.58 \mathrm{~g}$. The seeds were extracted manually, which were shiny black in colour. The seed length and seed width were recorded as $5.95 \pm 0.46 \mathrm{~mm}$ and $2.91 \pm 0.18 \mathrm{~mm}$. The initial moisture content of freshly extracted seeds was $20.86 \%$. 100 seed weight was recorded as $1.34 \pm 0.45 \mathrm{~g}$, while the seed purity was recorded as $93.98 \%$ (Table 1 ).

The results revealed that the initial viability of the seeds was $26.66 \%$ and it took 7.83 days to complete the germination with germination value of 0.65 . After two months of storage the germination increased in all the storage temperatures going up to $73.33 \%$ in $-20^{\circ} \mathrm{C}$ followed by $63.67 \%$ germination in $15^{\circ} \mathrm{C}$ as compared to $50 \%$ germination in seeds stored at ambient room temperature (Table 2). However, mean germination time also increased proportionally, longest being 44 days for seeds stored at $-20^{\circ} \mathrm{C}$ with 0.59 germination value. Similarly, after two months of storage the Germination Value (GV) of seeds also increased from initial GV (0.65) to maximum in 1.04 in $15^{\circ} \mathrm{C}$ as compared to seeds in control $(0.71)$ while it was minimum (0.54) in the seeds stored at $5^{\circ} \mathrm{C}$. After 4 months in storage, germination percentage increased to $60 \%$ in seeds stored at $5^{\circ} \mathrm{C}$ while, it reduced marginally in the ones stored at $15^{\circ} \mathrm{C}$ and $-20^{\circ} \mathrm{C}$, but more than $50 \%$ loss in viability was observed in seeds stored at RT (Table 3 ). Seeds stored at ambient temperature lost complete viability at 6 months while almost half the viability was lost in seeds stored at $15^{\circ} \mathrm{C}$ and $-20^{\circ} \mathrm{C}$, loss in germination value of seeds was also recorded due to loss in viability. Viability of seeds stored at all the three temperatures further dropped significantly $(p \leq 0.05)$ at 8 months and further at 10 
Table 1. Fruit and seed parameters of $B$. wallichiana.

\begin{tabular}{llll}
\hline S. N. & Parameter & Fruit & Seed \\
\hline 1. & Colour & Brown & Black \\
2. & Length $(\mathrm{mm})$ & $8.98 \pm 0.5$ & $5.95 \pm 0.46$ \\
3. & Width $(\mathrm{mm})$ & $8.39 \pm 0.47$ & $2.91 \pm 0.18$ \\
4. & Moisture Content \% & -- & $20.86 \pm 6.85$ \\
5. & Weight $(\mathrm{g}) 100$ individuals & $39.33 \pm 0.58$ & $1.34 \pm 0.45$ \\
6. & Purity \% & -- & $93.98 \pm 2.26$ \\
7. & Germination \% & -- & $26.66 \pm 5.77$ \\
\hline
\end{tabular}

Mean $\pm S D: 100$ individuals

Table 2. Effect of storage temperature on mean germination of seeds of $B$. wallichiana.

\begin{tabular}{|c|c|c|c|c|}
\hline \multirow{2}{*}{ Months } & \multicolumn{4}{|c|}{ Storage Temperatures } \\
\hline & RT & $5^{\circ} \mathrm{C}$ & $15^{\circ} \mathrm{C}$ & $-20^{\circ} \mathrm{C}$ \\
\hline 0 & $26.66 \pm 5.77$ & $26.66 \pm 5.77$ & $26.66 \pm 5.77$ & $26.66 \pm 5.77$ \\
\hline 2 & $50(45.0)$ & $53.33(46.92)$ & $66.67(54.78)$ & $73.33(59.71)$ \\
\hline 4 & $23.33(28.77)$ & $60(50.94)$ & $63.33(52.77)$ & $70(57.70)$ \\
\hline 6 & 0.0 & $40(39.15)$ & $36.67(33.89)$ & 26.67 (30.99) \\
\hline 8 & 0.0 & 30 (33.29) & $30(33.0)$ & $20(26.07)$ \\
\hline 10 & 0.0 & 26.67 (31.0) & $20(26.56)$ & $16.67(23.85)$ \\
\hline 12 & 0.0 & 23.33 (28.29) & 23.33 (28.77) & 16.67 (23.85) \\
\hline SEm & \multirow{2}{*}{\multicolumn{4}{|c|}{$\begin{array}{l}2.086 \\
4.172\end{array}$}} \\
\hline LSD @ $1 \%$ & & & & \\
\hline
\end{tabular}

Values in parentheses are arcsine transformed

Table 3. Effect of storage temperature on germination value and mean germination time of seeds of $B$. wallichiana.

\begin{tabular}{lcccccccc}
\hline Months & \multicolumn{3}{c}{$\mathbf{G V}$} & \multicolumn{4}{c}{ MGT (days) } \\
\cline { 2 - 9 } & $\mathbf{R T}$ & $\mathbf{5}^{\mathbf{0}} \mathbf{C}$ & $\mathbf{1 5}^{\mathbf{0}} \mathbf{C}$ & $\mathbf{- 2 0 ^ { 0 } \mathbf { C }}$ & $\mathbf{R T}$ & $\mathbf{5}^{\mathbf{C}} \mathbf{C}$ & $\mathbf{1 5 ^ { 0 } \mathbf { C }}$ & $\mathbf{- 2 0} \mathbf{C}$ \\
\hline 0 & 0.65 & 0.65 & 0.65 & 0.65 & 7.83 & 7.83 & 7.83 & 7.83 \\
2 & 0.71 & 0.54 & 1.04 & 0.59 & 23.17 & 25.70 & 32.13 & 44.37 \\
4 & 0.10 & 0.58 & 0.79 & 0.88 & 12.13 & 33.70 & 26.53 & 37.40 \\
6 & - & 0.30 & 0.50 & 0.30 & - & 19.47 & 16.83 & 11.33 \\
8 & - & 0.19 & 0.15 & 0.10 & - & 14.37 & 15.50 & 9.70 \\
10 & - & 0.21 & 0.07 & 0.06 & - & 11.17 & 9.53 & 9.23 \\
12 & - & 0.18 & 0.11 & 0.07 & - & 9.87 & 4.53 & 8.83 \\
\hline
\end{tabular}

months duration while MGT also decreased as seeds took less time for germination. Germination of seeds stored at $15^{\circ} \mathrm{C}$ increased from $20 \%$ to $23 \%$ at 12 months, this increase however was not significant. Seeds during storage got damaged and developed emptiness due to which the experiment could not be continued beyond 12 months. Longevity of seeds was assessed to be around 12 months and 5,15 and $-20^{\circ} \mathrm{C}$ were better suited storage temperature for longer viability of seeds.

\section{DISCUSSION}

The freshly collected seeds of $B$. wallichiana exhibited low viability ( $26 \%$ ) which increased up to $73 \%$, in the seeds stored at $-20^{\circ} \mathrm{C}$ followed by $67 \%$ viability at $15^{\circ} \mathrm{C}$ as compared to $50 \%$ in control (ambient room temperature) after two months in storage. The results observed might be due to the presence of shallow physiological dormancy in the seeds of $B$. wallichiana which may have broken down after getting prechilling treatment under low temperature storage conditions. In order to break the seed dormancy and get them germinated moist stratification for 30 days has been recommended for the seeds of $B$. wallichiana by Thapliyal et al. (2017). Similarly, Lazaro et al.
(2006) reported low seed germination in the five tested populations of Buxus balearica in the germination chamber where they recorded the maximum germination for the seeds collected from site Ragol I (41\%) while only $9 \%$ in the seeds collected from site Galatzo.

Similarly, very poor or no germination of $B$. sempervirens was reported by Cetin et al. (2015), while working on provenance variation of the species. They have reported only the seeds collected from Duzce province had about $1 \%$ germination rate at $15^{\circ} \mathrm{C}$ constant temperature while seeds from other provinces did not yield any germination. After four months of storage the viability of stored seeds declined gradually in all the storage conditions while rapidly in the seeds stored at ambient room temperature $(23 \%)$ (Table 2 ). The seeds of $B$. wallichiana exhibited the problem of emptiness (up to $50 \%$ ), during storage the seeds got spoilt (turned empty) due to which their longevity was observed to be about a year when stored at $5,15^{\circ} \mathrm{C}$ and sub zero temperature with seeds maintaining 26,13 and $16 \%$ viability, respectively, while no germination was recorded after four months of storage at ambient room temperature. It has been reported in other species of Buxus like B. microphylla that 
seeds cannot be dried and stored for long, dried seed germination rate was low and seeds did not germinate for a long period of time Likewise, Viswanath et al. (2006) observed that a high fraction of seeds of $B$. wallichiana do not remain viable for more than four to five months. This may be the reason why $B$. wallichiana seed bank dynamics appears to follow a transient strategy rather than a persistent seed bank strategy in nature.

\section{Conclusion}

Seed storage studies are very important for determining shelf life and viability of various types of seeds and devising strategy for their ex-situ conservation of the diversity of species through seeds. The longevity of the $B$. wallichiana seeds in the reported study was observed to be around 12 months when the seeds were stored at low temperatures maintaining the viability about $23 \%$ at $5^{\circ} \mathrm{C}$ and $15^{\circ} \mathrm{C}$. Although this investigation does provide preliminary evidences about longevity of the seeds of $B$. wallichiana but still there is a scope for more such studies on seeds of $B$. wallichiana from different provenances, to devise best strategy for conservation of the species.

\section{REFERENCES}

1. Cetin, B., Cicek, E., Esen, D., Kulaç, S., Ozbayram A. K. (2015). Some of the seed characteristics of common box (Buxus sempervirens) grown in different provinces of turkey. International Conference "Applied Ecology: Problems, Innovations" held at Iv. Javakhishvili Tbilisi State University Tbilisi, Batumi- 7 -10 May 2015.

2. Czabator, F.J. (1962). Germination value: An index combining speed and completeness of pine seed germination. Forest Science 8:386-395.

3. Govt. of India. (1986). The useful plants of India. CSIR Publication, Delhi

4. ISTA (2010). International Rules for Seed Testing 2010. International Seed Testing Association, Bassersdorf, Switzerland

5. Lazaro, A., Traveset, A. and Castillo, A. (2006). Spatial concordance at a regional scale in the regeneration process of a circum-Mediterranean relict (Buxus balearica): connecting seed dispersal to seedling establishment. Ecography 29: 683-696. https// doi:10.1111/j.2006.0906-7590.04667.x

6. Pant, S. (2011). Buxux wallichiana L., a multipurpose Himalayan tree in peril. International Journal of Biodiversity and Conservation. 3(5): 175-177.

7. Shirzad, G., Ehsan R.e and Mohsen N.M. (2013). Investigation of Ecological, Protective and Economic Status of Forest species Buxus hyrcana. Bulletin of Environment, Pharmacology and Life Sciences., 2 (12) $91-94$.

8. Thapliyal M., Rawat, P. and Saklani R. (2017). Seed dormancy and germination of Buxus wallichiana Linn.: An important woodcraft species. In Abstracts: XIX Commonwealth Forestry Conference, Forest Research Institute, Dehradun 34-35 pp.

9. Thapliyal, R. C. (1992). Seedset, seed dispersal, dormancy and germination in some temperate forest species of Western Himalayas: Problems and research needs. In: Forestry Research and Education in India- A Diamond Jubilee Publication, Indian National Science Academy (INSA), New Delhi.

10.Viswanath, S., Singh, R.P. and Thapliyal R.C. (2006). Seed bank dynamics of Buxus wallichiana Baillon. in a Himalayan moist temperate forest. Tropical Ecology 47(1): $145-148$.

11.Viswanath, S. (1999). Soil seed bank dynamics and germination ecophysiology of some selected species in a Himalayan moist temperate forest. Ph.D Thesis, Kumaun University, Nainital. 179p. 